
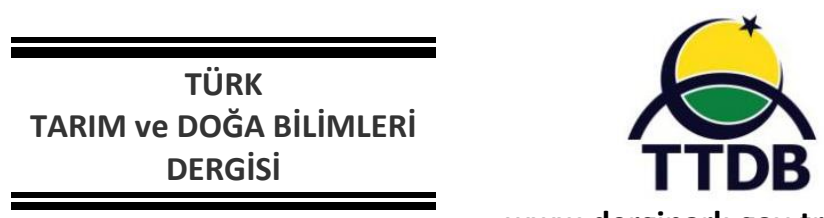

www.dergipark.gov.tr/turkjans

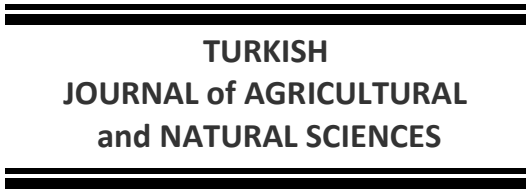

Araştırma Makalesi

\title{
Diyarbakır î Merkezinde Yaşayan Tüketicilerin Tavuk Eti Algıları ve Bu Algıları Etkileyen Faktörler Üzerinde Bir Araştırma
}

\author{
Turgay ŞENGÜL ${ }^{1 *}$, Selva ZEYBEK ${ }^{2}$ \\ ${ }^{1}$ Bingöl Üniversitesi Ziraat Fakültesi Zootekni Bölümü-Bingöl \\ ${ }^{2}$ Bingöl Üniversitesi Fen Bilimleri Enstitüsü Zootekni ABD-Bingöl \\ *Sorumlu yazar: tsengul2001@yahoo.com \\ Geliş Tarihi: 07.02.2020 Düzeltme Geliş Tarihi: 06.03.2020 Kabul Tarihi: 10.03.2020
}

\begin{abstract}
Özet
Bu çalışma, Diyarbakır Merkez ilçelerinde (Bağlar, Kayapınar, Yenişehir ve Sur) yaşayan tüketicilerin piyasadaki tavuk etiyle ilgili algılarının ve bu algıları etkileyen faktörlerin belirlenmesi amacıyla yapılmıştır. Çalışmada, Diyarbakır iline bağlı 4 merkez ilçeden toplam 281 tüketiciyle yapılan anket çalışmalarından elde edilen veriler kullanılmıştır. Araştırma sonuçlarına göre, tüketicilerin, özellikle yaş, eğitim durumu ve gelir seviyesine bağlı olarak tavuk etine yönelik yanlış ve olumsuz açıklamalardan etkilendiği belirlenmiştir. Tavuk etinin elde edilmesi aşamalarında, tüketicilerin büyük bir kısmının gerçek olmasa da inandığı bazı uygulamaların insanların algılarını olumsuz yönde etkilediği görülmüştür. Bu algı, tüketicileri tavuk eti yerine daha sağlıklı olduğunu düşündükleri kırmızı et tüketmeye yönlendirmektedir. Anket yapılan tüketicilerin büyük bir kısmı, etlik piliç üretiminde, hormon ve antibiyotik vb. katkıların kullanıldığına inandıklarını ve bu nedenle piyasadaki tavuk etini sağlıklı bulmadıklarını belirtmişlerdir. Bu olumsuz algının değişmesinde, tavuk eti arz zincirinin daha şeffaf hale getirilmesi ile tüketicilerin yetiştirme, kesim ve dağıtım sürecinin nasıl işlediğini bilmesi yarar sağlayabilecektir. Sonuç olarak, etlik piliç üretiminde, sadece piyasanın teknolojik ve ekonomik taleplerinin ele alınmasının yeterli olmadığı, üretilen piliç etinin sağlıklı ve güvenilir olduğu algısının da aynı derecede önem taşıdığı dikkate alınarak tüketicilerin bu konuda bilinçlendirilmesinin gerekli olduğu kanısına varılmıştır.
\end{abstract}

Anahtar kelimeler: Diyarbakır, Tavuk Eti, Tüketici Algısı, Pazarlama Stratejisi.

\section{A Research on Chicken Meat Perceptions of Consumers Living in Diyarbakır Province and Factors Affecting These Perceptions}

\begin{abstract}
This study was performed for identifying perceptions of consumers living in Bağlar, Kayapınar, Yenişehir and Sur districts in Diyarbakır province, in relation to chicken meat in the market and specifying factors affecting these perceptions. In the study, data obtained from interviews made with a total of 281 consumers from 4 central districts affiliated with Diyarbakır province were utilized. As per research results, it was found that consumers were influenced by erroneous and negative declarations about chicken meat depending particularly on age, education level and income level. It was discerned that human beings' perceptions were negatively affected by certain practices which were believed by the majority of consumers to be exercised in stages of chicken meat production even if they were untrue. This negative perception leads consumers to have red meat instead of chicken meat as they think that red meat is healthier than chicken meat. The majority of interviewed consumers reported that they believed that additives such as hormones and antibiotics were used in broiler production and therefore they did not think that the chicken meat in the market was healthy. Making the supply chain for chicken meat more transparent and informing consumers about how breeding, slaughter and distribution process works for chicken meat are likely to be helpful to change this negative perception. As a consequence, it was deduced that it was necessary to raise consumer awareness about this topic by paying attention to the fact that just addressing technological and economic demands of the market was not sufficient in broiler production but also promoting the perception that produced chicken meat was healthy and reliable was equally important.
\end{abstract}

Key words: Diyarbakır, Chicken Meat, Consumer Perception, Marketing Strategy. 


\section{Giriş}

Sağlıklı bir yaşam için yeterli ve dengeli beslenme çok önemlidir. Diyetisyenler, sağlıklı beslenmede hayvansal ürün tüketilmesinin büyük önem taşıdığını açıklamaktadır. Dengeli beslenmede, günlük protein ihtiyacının $\% 50$ 'sinin mutlaka hayvansal kaynaklı proteinlerden sağlanması gerektiği bildirilmiştir (Kızıloğlu ve ark., 2013; Bircan ve ark., 2017). Insanların ihtiyaç duyduğu hayvansal protein, kırmızı et, tavuk ürünleri ve balıktan sağlanabilmektedir. Tavuk eti, hayvansal protein ihtiyacının karşılanmasında, temel besin maddeleri bakımından zenginliği, diyet özellikleri, fiyatı, erişilebilirliği, tüketim alışkanlıkları ve bölgesel farklılıklar dikkate alındığında oldukça önemli bir kaynak durumundadır (Altan ve ark., 1993; Açıkgöz ve Özkan 1996; Hasipek ve Aktaş 1997; Çelik ve Şengül, 2001; İnci ve ark., 2014). Tavuk etinin, besin öğeleri açısından değerlendirildiğinde, daha kaliteli bir protein kaynağı olduğu, daha düşük enerji sağladığı ve daha az yağ ve doymuş yağ içeriğine sahip olduğu açıklanmıştır (Ertürk ve ark., 2014). Tüm dünyada, başta tavuk eti olmak üzere kanatlı etlerin üretimi ve tüketimi son yıllarda hızlı bir artış göstermiştir (Keskin ve Demirbaş, 2012). Son 20 yıllık süreçte diğer hayvan türlerinin aksine, kanatlı varlığında \%195 artış olmuştur (FAO, 2016). Kırmızı et üretiminde meydana gelen daralma, fiyatların yükselmesine, bunun sonucu olarak hayvansal protein açığının karşılanmasında tavukçuluk ürünlerinin tercih edilmesine neden olmaktadır (Şengül ve ark., 2002; Taşkın, 2003; Sayılı, 2006; Hekimoğlu ve Altındeğer 2009; IYKA, 2011). Sektördeki hızı gelişmeyle birlikte tavuk eti üretiminde 2000 yılına göre, 2015 yılında yaklaşık \%197'lik bir artış gözlenmiştir. Türkiye 2015 yılında, 1,9 milyon ton tavuk eti üretimi ile tarihinde rekor bir seviyeye ulaşmıştır. Bir önceki yıla göre, 2015 yılı üretim artış oranı \% 0,8 olmuştur. Ülkemiz, 2015 yılı itibariyle tavuk eti üretiminde dünyada 9. sırada yer almaktadır (TÜik, 2016). Türkiye'de kişi başına tavuk eti tüketimi yıllar itibariyle sürekli artış göstermiştir. Tavuk eti tüketimimiz, 2005 yılında 13,6 kg iken 2015 yılında \%60,2'lik bir artışla 21,8 kg'a yükselmiştir (BESD-BíR, 2016).

Tavuk eti tüketimi üzerine, kalite, fiyat, marka, hijyen, gelir düzeyi, yaş, alışkanlıklar, eğitim durumu ve meslek gibi pek çok faktör etkilidir (Cevger ve ark., 2008; Dölekoğlu ve Yurdakul
2004; Terin ve ark., 2014; Ikikat Tümer ve ark., 2016). Bunların dışında, tavuk eti tüketimini etkileyen ve sınırlayan diğer önemli bir faktör de, tavuk etinin sağlıklı ve güvenilir olmadığı ile ilgili oluşturulan yanlış ve olumsuz algılardır. Bu algılar, genellikle TV kanallarında konu hakkında bilgisi ve uzmanlığı olmayan medyatik tıp doktorları tarafından oluşturulmaktadır. Bu konudaki yayınlar, TV kanallarını izleyen milyonlarca tüketici üzerinde yanlış ve asılsız bilgilerle tavuk eti hakkında olumsuz bir yargı oluşturmaktadır. Bu durum, kanatlı sektörünün geleceği açısından ciddi bir sorun teşkil etmekte ve üzerinde önemle durulması gerekmektedir. Etlik piliç üretiminde, hayvanların kısa sürede çok hızlı canlı ağırlık artışı sağlaması ve piliç etinin kısa sürede pişmesi gibi durumlar, bilinçsizce, hormon-antibiyotik kullanımı ve GDO'lu (Genetiği Değiştirilmiş Organizma) yemlerle beslemeye bağlanarak tavuk etinin kanser riskini arttırdığı iddia edilmektedir. Bunlara ilaveten, piliçlerin genetik yapısının hibrit olması, kümeslerde birim alanda fazla sayıda hayvan bulundurulması nedeniyle hayvanların hareketsizliği ve kümesteki yetersiz havalandırma gibi olumsuzluklar da dikkatlere sunularak tüketiciler yanlış yönlendirilmektedir.

$\mathrm{Bu}$ araştırmada, beslenmede önemli bir yeri olan tavuk etinin tüketimine ilişkin tüketici algıları ile bu algıları oluşturan etmenler ve tüketimlerinde etkili olan tercih ve düşüncelerinin ortaya konulması amaçlanmıştır.

\section{Materyal ve Yöntem}

$\mathrm{Bu}$ araştırmanın materyalini, Diyarbakır iline bağlı 4 merkez ilçede (Bağlar, Kayapınar, Yenişehir ve Sur), toplam 281 tüketiciyle yüz yüze yapılan anket uygulamasından elde edilen veriler oluşturmuştur. Diyarbakır il merkezinde yaşayan tüketicilerin tavuk eti hakkındaki algılarının ve bu algılara neden olan etmenlerin belirlenmesi amacıyla veri toplama aracı olarak toplam 42 soruyu içeren anket formu hazırlanmıştır. Anket çalışmaları, 2018 yılının Temmuz-Ağustos aylarında yapılmıştır. Anket soruları, tüketicilerin tavuk eti konusundaki kişisel tercihlerini, algılarını, davranışlarını ve tüketim alışkanlıklarını saptamaya yönelik olarak hazırlanmıştır. Ayrıca, sosyo-ekonomik

ve demografik özellikler ile tavuk eti tüketimi arasındaki ilişkilerin belirlenmesi hedeflenmiştir. Araştırmada kullanılmak amacıyla hazırlanan anket formlarında, tüketicilerin yaşı, öğrenim durumu, aylık geliri, 
mesleği, tavuk eti hakkındaki düşünceleri ve tüketim tercihleri ile ilgili sorular sorulmuştur. Araştırmada, Diyarbakır merkez ilçelerde yaşayan 21-70 yaş grubunda toplam 281 tüketici ile görüşülerek gerekli veriler sağlanmıştır. Anket yapılan tüketici sayısını (örnek hacmini) belirlemek için aşağıdaki formül kullanılmıştır (Baş, 2008).

$$
n=\frac{N>t^{2} \times p \times q}{d^{2} \times(N-1)+t^{2} \times p>q}
$$

Formülde;

$\mathrm{n}$ : örneğe alınacak birey sayısı

$\mathrm{N}$ : hedef kitledeki birey sayısı (1.047.286)

$\mathrm{p}$ : incelenen olayın gerçekleşme olasılığı (0.50)

q: incelenen olayın gerçekleşme olasılığı (0.50)

t: standart normal dağılım değeri (1.96)

$\mathrm{d}$ : örnekleme hatası (0.05)'dır.

Elde edilen verilerin analizinde tek yönlü varyans analizden yararlanılmıştır. Özellikler arasında herhangi bir ilişki olup olmadığını ortaya koyabilmek amacıyla ise Ki-kare $\left(\chi^{2}\right)$ analizi yapılmıştır. İstatistiksel analizlerin uygulanmasında SPSS 19.0 Windows programı kullanılmıştır.

\section{Araştırma Bulguları ve Tartışma}

Tüketicilerin Sosyo-Demografik ve Ekonomik Özellikleri
Diyarbakır ilinin merkez ilçelerine ait nüfus, nüfus oranı ve yapılan anket sayısı Çizelge 1 'de, anket yapılan tüketicilerin cinsiyetler itibariyle ilçeler bazında dağılımına ait sayı ve oranlar ise Çizelge 2'de verilmiştir. Anket yapılan tüketicilerin \%66,5'inin erkek, \%33,5'inin kadın olduğu belirlenmiştir. Bağlar ilçesinde anket yapılan tüketicilerin \%60,5'inin erkek, \%39,5'inin kadın, Kayapınar ilçesinde \%68,4'ünün erkek, $\% 31,6$ 'sının kadın, Sur ilçesinde \%73,3'ünün erkek, \%26,7'sinin kadın ve Yenişehir ilçesinde ise $\% 70,9$ 'unun erkek, \%29,1'inin kadın olduğu saptanmıştır.

Anket yapılan tüketicilerin yaş grupları itibariyle ilçeler bazında dağılımına ait sayı ve oranları Çizelge 3'te verilmiştir. Anket yapılan tüketicilerin $\% 44,1^{\prime}$ inin $21-30$ yaş, $\% 25,2^{\prime}$ sinin 31 40 yaş, \%21,3'ünün $41-50$ yaş, $\% 8,5^{\prime}$ inin $51-60$ yaş ve $\% 0,7^{\prime} \operatorname{sinin}$ ise $61-70$ yaş grubunda yer aldıkları belirlenmiştir.

Çizelge 1. Diyarbakır’ın merkez ilçelerine ait nüfus, nüfus oranı ve yapılan anket sayısı.

\begin{tabular}{lccc} 
İlçe Adı & İlçe nüfusu & Oran (\%) & Anket sayısı (adet) \\
\hline Bağlar & 386.578 & 36.9 & 104 \\
Kayapınar & 342.977 & 32.7 & 52 \\
Yenişehir & 204.284 & 19.5 & 30 \\
Sur & 113.447 & 10.9 & 281 \\
Toplam & 1.047 .286 & 100 & 28
\end{tabular}


Çizelge 2. Tüketicilerin cinsiyetler itibariyle ilçeler bazında dağılımı.

\begin{tabular}{lcccccccccc}
\hline & \multicolumn{2}{c}{ Bağlar } & \multicolumn{2}{c}{ Kayapınar } & \multicolumn{2}{c}{ Sur } & \multicolumn{2}{c}{ Yenişehir } & \multicolumn{2}{c}{ Toplam } \\
\cline { 2 - 11 } Cinsiyet/ilçce & Sayı & $\%$ & Sayı & $\%$ & Sayı & $\%$ & Sayı & $\%$ & Sayı & $\%$ \\
\hline Erkek & 63 & 60,5 & 63 & 68,4 & 22 & 73,3 & 39 & 70,9 & 187 & 66,5 \\
Kadın & 41 & 39,5 & 29 & 31,6 & 8 & 26,7 & 16 & 29,1 & 94 & 33,5 \\
Toplam & 104 & 100,0 & 92 & 100,0 & 30 & 100,0 & 55 & 100,0 & 281 & 100,0 \\
\hline
\end{tabular}

Çizelge 3. Tüketicilerin yaş grupları itibariyle ilçeler bazında dağılımı.

\begin{tabular}{lcccccccccc}
\hline \multirow{2}{*}{ Yaş/ilçe } & \multicolumn{2}{c}{ Bağlar } & \multicolumn{2}{c}{ Kayapınar } & \multicolumn{2}{c}{ Sur } & \multicolumn{2}{c}{ Yenişehir } & \multicolumn{2}{c}{ Toplam } \\
\cline { 2 - 10 } & Sayı & $\%$ & Sayı & $\%$ & Sayı & $\%$ & Sayı & $\%$ & Sayı & $\%$ \\
\hline $21-30$ & 46 & 44,2 & 47 & 51,0 & 5 & 16,6 & 26 & 47,2 & 124 & 44,1 \\
$31-40$ & 26 & 25,0 & 22 & 23,9 & 13 & 43,3 & 10 & 18,1 & 71 & 25,2 \\
$41-50$ & 24 & 23,0 & 17 & 18,4 & 6 & 20,0 & 13 & 23,6 & 60 & 21,3 \\
$51-60$ & 7 & 6,7 & 6 & 6,5 & 5 & 16,6 & 6 & 10,9 & 24 & 8,5 \\
$61-70$ & 1 & 0,9 & 0 & 0,0 & 1 & 3,3 & 0 & 0,0 & 2 & 0,7 \\
Toplam & 104 & 100,0 & 92 & 100,0 & 30 & 100,0 & 55 & 100,0 & 281 & 100,0 \\
\hline
\end{tabular}

Çizelge 4. Tüketicilerin eğitim durumlarının ilçeler bazında dağılımı.

\begin{tabular}{lcccccccccc}
\hline \multirow{2}{*}{$\begin{array}{l}\text { düitim } \\
\text { durumu/ilçe }\end{array}$} & \multicolumn{2}{c}{ Bağlar } & \multicolumn{2}{c}{ Kayapınar } & \multicolumn{2}{c}{ Sur } & \multicolumn{2}{c}{ Yenişehir } & \multicolumn{2}{c}{ Toplam } \\
\cline { 2 - 11 } & Sayı & $\%$ & Sayı & $\%$ & Sayı & $\%$ & Sayı & $\%$ & Sayı & $\%$ \\
\hline Okuryazar & 3 & 2,8 & 3 & 3,2 & 1 & 3,3 & 2 & 3,6 & 9 & 3,2 \\
Ilkokul & 8 & 7,6 & 6 & 6,5 & 2 & 6,6 & 3 & 5,4 & 19 & 6,7 \\
Ortaokul & 14 & 13,4 & 9 & 9,7 & 4 & 13,3 & 5 & 9,0 & 32 & 11,3 \\
Lise & 22 & 21,1 & 19 & 20,6 & 3 & 10,0 & 14 & 25,4 & 58 & 20,6 \\
Üniversite & 57 & 54,8 & 55 & 59,7 & 20 & 66,6 & 31 & 56,3 & 163 & 58,0 \\
Toplam & 104 & 100,0 & 92 & 100,0 & 30 & 100,0 & 55 & 100,0 & 281 & 100,0 \\
\hline
\end{tabular}

Çizelge 5. Tüketicilerin meslek gruplarının ilçeler bazında dağılımı.

\begin{tabular}{|c|c|c|c|c|c|c|c|c|c|c|}
\hline \multirow{2}{*}{$\begin{array}{l}\text { Meslek/ } \\
\text { İlçeler }\end{array}$} & \multicolumn{2}{|c|}{ Bağlar } & \multicolumn{2}{|c|}{ Kayapınar } & \multicolumn{2}{|c|}{ Sur } & \multicolumn{2}{|c|}{ Yenişehir } & \multicolumn{2}{|c|}{ Toplam } \\
\hline & Sayı & $\%$ & Sayı & $\%$ & Sayı & $\%$ & Sayı & $\%$ & Sayı & $\%$ \\
\hline Memur & 35 & 33,9 & 31 & 36,0 & 16 & 53,4 & 18 & 34,6 & 100 & 36,9 \\
\hline S. Meslek & 37 & 35,9 & 31 & 36,0 & 4 & 13,3 & 13 & 25,0 & 85 & 31,3 \\
\hline İşçi & 16 & 15,5 & 8 & 9,3 & 10 & 33,3 & 12 & 23,0 & 46 & 16,9 \\
\hline Emekli & 3 & 2,9 & 4 & 4,6 & 0 & 0,0 & 1 & 1,9 & 8 & 2,9 \\
\hline Öğrenci & 12 & 11,6 & 12 & 13,9 & 0 & 0,0 & 8 & 15,3 & 32 & 11,8 \\
\hline Toplam & 103 & 100,0 & 86 & 100,0 & 30 & 100,0 & 52 & 100,0 & $271^{*}$ & 100,0 \\
\hline
\end{tabular}

* 10 kişi bu soruya cevap vermemiştir.

Anket yapılan tüm ilçeler genelinde, üniversite mezunu olan tüketicilerin oranı $\% 58$, lise mezunu olan tüketicilerin oranı $\% 20,6$, ortaokul mezunu olan tüketicilerin oranı $\% 11,3$, ilkokul mezunu olan tüketicilerin oranı $\% 6,7$ ve okuryazar olan tüketicilerin oranı ise \%3,2 olarak bulunmuştur (Çizelge 4).

Meslek grupları itibariyle tüketicilerin ilçelere göre dağılımı Çizelge 5'te verilmiştir. Genel olarak anket yapılan tüketicilerin \%36,9'unun memur, \%31,3'ünün serbest meslek, \%16,9'unun işçi, \%11,8'inin öğrenci ve $\% 2,9$ 'unun ise emekli grubunda olduğu belirlenmiştir.

İlçeler itibariyle aylık geliri 1500-2500 TL olan tüketicilerin oranı $\% 42,7,2501-3500 \mathrm{TL}$ olanların oranı $\% 18,6,3501-4500$ TL olanların oranı \%16,4, 4501-5500 TL olanların oranı $\% 16,7$ ve 5501 TL ve üstünde olanların oranı ise $\% 5,4$ olarak bulunmuştur (Çizelge 6). 
Çizelge 6. Tüketicilerin aylık gelir gruplarına göre ilçeler bazında dağılımı (TL).

\begin{tabular}{lcccccccccc}
\hline \multirow{2}{*}{$\begin{array}{l}\text { Aylık } \\
\text { Gelir/ilçe }\end{array}$} & \multicolumn{3}{c}{ Bağlar } & \multicolumn{2}{c}{ Kayapınar } & \multicolumn{2}{c}{ Sur } & \multicolumn{2}{c}{ Yenişehir } & \multicolumn{2}{c}{ Toplam } \\
\cline { 2 - 11 } & Sayı & $\%$ & Sayı & $\%$ & Sayı & $\%$ & Sayı & $\%$ & Sayı & $\%$ \\
\hline $1500-2500$ & 46 & 45,0 & 43 & 47,2 & 7 & 23,3 & 21 & 41,1 & 117 & 42,7 \\
$2501-3500$ & 21 & 20,5 & 14 & 15,3 & 5 & 16,6 & 11 & 21,5 & 51 & 18,6 \\
$3501-4500$ & 15 & 14,7 & 14 & 15,3 & 7 & 23,3 & 9 & 17,6 & 45 & 16,4 \\
$4501-5500$ & 14 & 13,7 & 13 & 14,2 & 10 & 33,3 & 9 & 17,6 & 46 & 16,7 \\
$5501+$ & 6 & 5,8 & 7 & 7,6 & 1 & 3,3 & 1 & 1,9 & 15 & 5,4 \\
Toplam & 102 & 100,0 & 91 & 100,0 & 30 & 100,0 & 51 & 100,0 & 274 & 100,0 \\
\hline
\end{tabular}

Tüketicilerin günümüzdeki gıdaların ve etlik piliç etlerinin sağlıklı olup olmaması konusundaki düşünceleri

Ankete katılan tüketicilerin, \%69'u günümüzde tüketilen gıdaların 30 yıl öncesine göre daha kalitesiz ve sağlıksız olduğunu, \%21'i daha iyi olduğunu, \%10'u ise herhangi bir fikri olmadığını ifade etmişlerdir. Etlik piliçlerin yetiştirilme şartlarının etlerinin kalitesi ve sağlıklı olup olmamasına etkisi sorulduğunda, tüketicilerin \%88'i etkiler, \%7'si etkilemez, $\% 5$ 'ise fikrim yok diye cevaplamışlardır. Tüketicilerin yarısından fazlası (\%53) etlik piliçlerin hibrit genotipte olması nedeniyle etlerinin sağlıklı olmadığını düşünmektedirler. Tüketicilerin \%82'sinin etlik piliçlerin genetik yapılarıyla oynandığından dolayı piyasada satılan tavuk etlerinin doğal olmadığını ve bu nedenle sağlık açısından sakıncalı olabileceğini düşündükleri belirlenmiştir. Tavukçuluk konusunda uzman olmayan kişilerin (özellikle tıp doktorları) TV kanallarında tavuk eti hakkındaki yanlış ve olumsuz konuşmalarının tüketicilerin tavuk eti tüketimi üzerine etkisi incelenmiştir. Yapılan anketlerde, tüketicilerin $\% 62$ 'si tavuk eti hakkında medyadaki olumsuz konuşmalardan etkilendiklerini, \%38'i ise bu sebeple tavuk eti tüketimlerini önemli düzeyde azalttıklarını belirtmişlerdir. Tüketicilerin $\% 55^{\prime} i$, TV kanallarında piyasadaki tavuk etlerinin sağlıksız olduğu konusunda yapılan açıklamalara katıldıklarını ifade etmişlerdir. Tüketicilere, piliç etinin sağlıklı olduğuna nasıl ikna olacakları sorusuna, \%65'i hiçbir şekilde ikna olmayacağını, \%32'si ikna olmasının çok zor olduğu, \%34'ü ise tüm uzmanların bu konuda hem fikir olduğunda ikna olabileceği şeklinde cevap vermişlerdir. Adana ili kentsel alanında yapılan bir araştırmada, tüketicilerin $\% 98,7$ 'sinin TV, radyo ve gazetelerde tavuk etinde hormon, antibiyotik kullanımı ve kuş gribi hastalığı ile ilgili görüşlerden haberdar olduğu ve bu haberler sonrasında ailelerin \%56'sının tavuk eti tüketimlerini azalttıkları bildirilmiştir (Büyüknisan, 2008). Kars ilinde yapılan bir çalışmada, tüketicilerin hormon ve antibiyotik kullanımına ilişkin çıkan haberler doğrultusunda \%70'inin tavuk etini riskli olarak gördükleri ve özellikle gelir durumu yüksek olan tüketicilerin tüketimlerini önemli ölçüde azaltırken, gelir seviyesi düşük olanların fiyatın düşmesine bağlı olarak tüketimlerini arttıkları belirlenmiştir (Ayvazoğlu Demir ve Aydın, 2018). Bingöl ili merkez ilçede, Karakaya ve İnci (2014)'nin yapmış olduğu çalışmada, yetiştiricilikte ilaç veya katkı maddesi kullanımını tüketicilerin tavuk eti tüketimlerini olumsuz yönde etkileyen faktörler içinde 2 . sırada bulmuşlardır. Artvin'de yapılan bir araştırmada ise, medyada yer alan haberlerin bireylerin tavuk eti tüketimini olumlu ya da olumsuz yönde etkileyip etkilemediği incelenmiş ve öğrencilerin $\% 50,2^{\prime}$ sinin bu haberlerden etkilendiği, \%49,8'inin ise etkilenmediği belirlenmiştir (İskender ve ark., 2015). Çalışmadan elde edilen sonuçların, bu konuda yapılan önceki çalışmalara ait bulgularla büyük ölçüde benzerlik gösterdiği saptanmıştır.

\section{Etlik Piliçlerin Üretiminde Sağlık Açısından Zararlı Olan Bazı Katkıların (Hormon, Antibiyotik vb.) Kullanımı Konusundaki Tüketici Algıları}

Anket yapılan tüketicilerin \%72'si etlik piliç üretiminde kesinlikle hormon kullanıldığını, $\% 20$ 'si ise muhtemelen kullanıldığını, \%5'i bu konuda bilgisinin olmadığını,\%3'ü ise hormon kullanıldığına inanmadıklarını ifade etmişlerdir. Hormonların kansere neden olduğunu söyleyen bireylerin oranı $\% 75$ olarak belirlenmiştir. Gerçek konu uzmanlarının piliç üretiminde hormon ve antibiyotik kullanımı yoktur açıklamaları sizi tatmin etmiyor mu? sorusuna tüketicilerin $\% 89$ 'u tatmin etmiyor cevabını vermişlerdir. Tüketicilerin, etlik piliçlerin kısa sürede çok hızlı büyümesine genetik çalışmalar 
ve besleme konusundaki gelişmelerin neden olduğu açıklamasına inanıp inanmadığı sorusuna tüketicilerin \%60'ı inanmadığını, \%32'si inandığını, \%8'i ise fikrinin olmadığını ifade etmişlerdir. Tüketicilerin $\% 52$ 'si etlik piliç üretiminde antibiyotik kullanıldığına ve piliç etinde kalıntı olduğuna inandıklarını, \%82'si de antibiyotik kullanım yasağının uygulanıp uygulanmadığı konusunda endişeli olduklarını söylemişlerdir. Antibiyotik kullanılmıyor diyenlerin oranı \%32, fikrim yok diyenlerin oranı ise \%16 olarak belirlenmiştir. Tüketicilerin, $\% 59$ 'u etlik piliç yemlerinde GDO'lu yem hammaddesi kullanıldığını, \%84'ü GDO'lu yem hammaddesi kullanımına kesinlikle karşı olduğunu, \%87'si ise GDO'lu yemlerle beslenen tavukların etlerinin sağlık açısından sakıncalı olduğunu ifade etmişlerdir. Tüketicilerin \%38'i yemlerde GDO'lu hammadde kullanılıp kullanılmadığı konusunda bilgi sahibi olmadığını, \%3'ü ise kullanılmadığını söylemişlerdir.

\section{Tavuk Eti Tüketimiyle Ilgili Tüketici Düşünceleri}

Tüketicilerin \%55'i sağlıklı beslenmek için tavuk etinin mutlaka tüketilmesi gerektiğini, \%33'ü gerekli olmadığını, \%12'si bu konuda fikri olmadığı beyan etmişlerdir. Anket yapılan bireylerin \%50'si protein ihtiyacını karşılamak için tavuk eti yerine diğer gıdaların tüketilebileceğini belirtmişlerdir. Tüketicilere hangi tür eti daha çok tercih ettikleri sorulduğunda, \%53'ü kırmızı et, \%47'si ise tavuk eti şeklinde cevap vermişlerdir. Tüketicilerin, kırmızı eti daha çok, besleyici, lezzetli, sağlıklı, güvenli ve lezzetli buldukları için, tavuk etini ise daha çok ekonomik olduğu için tercih ettikleri belirlenmiştir. Tüketilen et türü ve sebebi arasındaki ilişki istatistiki olarak önemli bulunmuştur (Çizelge 7).

Çizelge 7. Tüketicilerin kırmızı et ve tavuk etini tercih nedenleri.

\begin{tabular}{lcc}
\hline Tercih nedeni & Kırmızı et (\%) & Tavuk eti (\%) \\
\hline Besin değerinin yüksek olması & 81,8 & 18,2 \\
Lezzetli olması & 83,3 & 16,7 \\
Sağlıklı olması & 95,5 & 4,5 \\
Ekonomik olması & 2,1 & 97,9 \\
Güvenilir olması & 100,0 & 0,0 \\
Alışkanlık & 73,9 & 26,1 \\
Ki-kare değeri*** & & 22,394 \\
\hline
\end{tabular}

$* * *(\mathrm{P}<0.001)$.

Tüketicilerin \%39'u, organik tavuk veya köy tavuğu bulamadıkları için, \%26'sı ise ucuz olması nedeniyle sağlıklı bulmasalar da piliç etini tükettiklerini bildirmişlerdir. Tüketicilerin \%7'si organik veya köy tavuğu bulabilseler bile fiyatının çok yüksek olduğunu söylemiştir. Tüketicilerin \%50'si piyasada gerçekten organik piliç eti satıldığına inanmadıklarını ifade etmişlerdir. Gerçek organik piliç eti satın almak için tüketicilerin \%45'inin 1.5-2 kat yüksek fiyat verebilecekleri saptanmıştır. Koç (2010) tarafından, Bitlis'in Adilcevaz ilçesinde yapılan bir çalışmada, kentsel alandaki tüketicilerin öncelikli olarak daha çok kırmızı et, kırsal alandaki tüketicilerin ise tavuk eti ve kırmızı eti birlikte tükettiği sonucu belirlenmiştir. Çalışmada, tavuk eti tüketimine öncelik verilme nedeni olarak, kolay ve pratik olması gösterilmiştir. Topuzoğlu ve ark., (2007) tarafından İstanbul ili Ümraniye ilçesinde yürütülen diğer bir araştırmada, bireylerin $\% 67,1^{\prime}$ inin hormonsuz ürünlere fazla ödeme yapmaya razı olacağı ve $\% 77,2^{\prime}$ sinin katkı maddesi kullanılmamasını önemseme fikrine katıldıkları belirlenmiştir. Karakaya ve İnci (2014)'nin Bingöl ilinde yapmış olduğu bir çalışmada ise, bireylerin \%70'inin tavuk eti tüketmeyi tercih ederken, \%30'unun kırmızı eti tüketmeyi tercih ettiklerini bildirilmiştir. Tavuk eti tüketiminde öncelikli nedenler olarak, sağlıklı olması, lezzetli olması ve alışkanlıklar bildirilmiştir.

\section{Sosyo-Demografik Özellikler ile Tavuk Eti Tüketimi Arasındaki ilişki}

Yaş grupları itibariyle tüketicilerin \%54,8'i sağlıklı beslenmek için tavuk etinin mutlaka tüketilmesi gerektiğini, $\% 33,5^{\prime} i$ ise gerekli olmadığını ifade ederken, \%11,7'si ise bu konuda fikri olmadığını belirtmişlerdir (Çizelge 8). Özellikle, 60 yaşından büyük olan tüketiciler sağlıklı beslenmek için tavuk etinin tüketilmesi gerekmediği, 31-40 yaş arasında olan tüketicilerin ise diğer yaş gruplarına nazaran 
sağlıklı beslenmek için tavuk eti tüketilmesi gerektiği fikrine sahip oldukları tespit edilmiştir. Yaş grupları ve tavuk eti tüketip tüketmeme durumu arasında istatistiksel olarak önemli bir ilişki bulunmamıştır.

Çizelge 8. Tüketicilerin yaş grupları ile tavuk eti tüketimi arasındaki ilişki.

Sağlıklı beslenmek için tavuk etinin mutlaka tüketilmesi gerekli midir?

Yaş grupları

\begin{tabular}{lcccc}
\cline { 2 - 4 } Yaş grupları & Evet (\%) & Hayır (\%) & Fikrim yok (\%) & Toplam \\
\hline $21-30$ & 54.0 & 30,6 & 15,4 & 100 \\
$31-40$ & 63,4 & 29,6 & 7,0 & 100 \\
$41-50$ & 48,3 & 43,3 & 8,3 & 100 \\
$51-60$ & 54,2 & 29,2 & 16,7 & 100 \\
$61-70$ & - & 100,0 & - & 100 \\
Ortalama & 54,8 & 33,5 & 11,7 & 100 \\
Ki-kare değeri & & \multicolumn{2}{c}{12,081} &
\end{tabular}

Eğitim grupları itibariyle tavuk eti tüketip tüketmeme durumu arasındaki ilişki Çizelge 9 'da verilmiştir. Tüm eğitim grupları açısından sağlıklı beslenmek için tavuk etinin mutlaka tüketilmesi gerekir fikrine tüketicilerin katılım oranı $\% 54,8$, gerekli değildir fikrine katılım oranı
$\% 33,5$ ve fikrim yok diyen tüketicilerin oranı ise $\% 11,8$ olarak bulunmuştur. Eğitim grupları ve tavuk eti tüketip tüketmeme durumu arasında istatistiksel olarak önemli bir ilişki bulunmamıştır.

Çizelge 9. Eğitim grupları ile tavuk eti tüketimi arasındaki ilişki.

\begin{tabular}{lcccc}
\hline & \multicolumn{3}{c}{ Sağlıklı beslenmek için tavuk etinin mutlaka tüketilmesi gerekli midir? } \\
\cline { 2 - 5 } & Evet (\%) & Hayır (\%) & Fikrim yok (\%) & Toplam \\
\hline Okuryazar & 66,7 & 33,3 & - & 100 \\
Ilkokul & 52,6 & 42,1 & 5,3 & 100 \\
Ortaokul & 56,3 & 37,5 & 6,4 & 100 \\
Lise & 51,7 & 25,9 & 22,4 & 100 \\
Üniversite & 55,2 & 34,4 & 10,4 & 100 \\
Ortalama & 54,8 & 33,5 & 11,8 & 100 \\
Ki-kare değeri & & & \multirow{2}{*}{13,011} & \\
\hline
\end{tabular}

Cinsiyetler itibariyle, "sağlıklı beslenmek için tavuk etinin mutlaka tüketilmesi gerekli midir" fikrine tüketicilerin katılım oranı erkekler için \%54,5, kadınlar için \%55,3; "tüketilmesi gerekli değildir" fikrine katılım oranı erkekler için \%32,1, kadınlar için \%36,2 ve fikrim yok diyen tüketicilerin oranı ise erkekler için \%13,4, kadınlar için \%8,5 olarak bulunmuştur. Cinsiyetler açısından tavuk eti tüketip tüketmeme durumu arasında istatistiksel olarak önemli bir ilişki bulunmamıştır (Çizelge 10).

Çizelge 10. Cinsiyet ile tavuk eti tüketimi arasındaki ilişki.

\begin{tabular}{|c|c|c|c|c|}
\hline \multirow{2}{*}{ Cinsiyet } & \multicolumn{4}{|c|}{ Sağlıklı beslenmek için tavuk etinin mutlaka tüketilmesi gerekli midir? } \\
\hline & Evet (\%) & Hayır (\%) & Fikrim yok (\%) & Toplam \\
\hline Erkek & 54,5 & 32,1 & 13,4 & 100 \\
\hline Kadın & 55,3 & 36,2 & 8,5 & 100 \\
\hline Ortalama & 54,8 & 33,5 & 11,7 & 100 \\
\hline Ki-kare değeri & \multicolumn{4}{|c|}{2,883} \\
\hline
\end{tabular}


Meslek gruplarına bakıldığında, işçi grubunda yer alan tüketiciler diğer meslek gruplarındaki tüketicilere göre sağlıklı beslenmek için tavuk etinin mutlaka tüketilmesi gerekir fikrine daha fazla (\%58.7) katılırken, öğrencilerin \%50'si bu fikre katıldıklarını ifade etmişlerdir. Emekli grubunda yer alan tüketicilerin yarısı ise, öğrencilerin aksine sağlıklı beslenmek için tavuk eti tüketmek gerekli değildir fikrinde olduklarını beyan etmişlerdir. Meslek grupları açısından tavuk eti tüketip tüketmeme durumu arasında istatistiksel olarak önemli bir ilişki bulunmamıştır (Çizelge 11).

Çizelge 11. Meslek grupları ile tavuk eti tüketimi arasındaki ilişki.

\begin{tabular}{lcccc}
\hline \multirow{2}{*}{ Meslek grupları } & \multicolumn{3}{c}{ Sağlıklı beslenmek için tavuk etinin mutlaka tüketilmesi gerekli midir? } \\
\cline { 2 - 5 } & Evet (\%) & Hayır (\%) & Fikrim yok (\%) & Toplam \\
\hline Memur & 57,0 & 34,0 & 9,0 & 100 \\
Serbest meslek & 55,4 & 31,8 & 13,0 & 100 \\
İşçi & 58,7 & 34,8 & 6,5 & 100 \\
Emekli & 25,0 & 50,0 & 25,0 & 100 \\
Öğrenci & 50,0 & 28,1 & 21,9 & 100 \\
Ortalama & 55,6 & 33,3 & 11,1 & 100 \\
Ki-kare değeri & & & & \\
\end{tabular}

Gelir grupları ile tavuk eti tüketip tüketmeme durumu arasında istatistiksel olarak önemli bir ilişki bulunmamış, tüm gelir grupları itibariyle tavuk etinin tüketilmesi gerekir fikrine katılanların oranı $\% 54,8$, katılmayanların oranı $\% 33,5$ ve fikrim yok diyenlerin oranı ise \%11,7 olarak bulunmuştur (Çizelge 12). Sağlıklı beslenmek için tavuk etinin mutlaka tüketilmesi gerekli midir? sorusuna en yüksek oranda evet cevabı (\%64.4) gelir düzeyi 3501-4500 TL arasında olan gruptan alınırken, en düşük evet cevabı (\%46.7) 5501 ve üstü gelir düzeyine sahip gruptan elde edilmiştir.

Çizelge 12. Gelir grupları ile tavuk eti tüketimi arasındaki ilişki.

\begin{tabular}{lcccc}
\hline \multirow{2}{*}{ Gelir grupları (TL) } & \multicolumn{4}{c}{ Sağlıklı beslenmek için tavuk etinin mutlaka tüketilmesi gerekli midir? } \\
\cline { 2 - 5 } & Evet (\%) & Hayır (\%) & Fikrim yok (\%) & Toplam \\
\hline $1500-2500$ & 50,4 & 34,2 & 15,4 & 100 \\
$2501-3500$ & 54,9 & 33,3 & 11,8 & 100 \\
$3501-4500$ & 64,4 & 28,9 & 6,7 & 100 \\
$4501-5500$ & 58,7 & 34,8 & 6,5 & 100 \\
5501 ve üstü & 46,7 & 46,7 & 6,6 & 100 \\
Ortalama & 54,8 & 33,5 & 11,7 & 100 \\
Ki-kare değeri & & \multirow{2}{*}{12,716} & \\
\hline
\end{tabular}

Yapılan bir çalışmada, kentsel alanda yaşayan hane halkının \%92,39'unun, kırsal alanda yaşayan hane halkının \%95,56'sının tavuk etinin sağlık açısından faydalı olduğu görüşünde olduğu tespit edilmiştir (Koç, 2010). Uluat (2002) tarafından, Van ili merkez ilçede yapılan bir çalışmada, tüketicilerin \%96,7'si tavuk etinin sağlığa yararlı olduğunu belirtmiştir. Ayrıca, katılımcıların \%63'ü kanatlı eti tüketiminin sağlıklı beslenme için mutlaka gerekli olduğunu ifade etmişlerdir. Çalışma sonuçları, daha önce yapılmış olan çalışma bulguları ile benzerlik göstermektedir.

\section{Sosyo-Demografik Özellikler itibariyle Tüketicilerin Tercih Ettikleri Et Türü}

Sosyo-demografik özellikler itibariyle tüketicilerin daha çok tükettiği et türüne ait dağılımlar Çizelge 13'te verilmiştir. Cinsiyetler itibariyle, tavuk etinin daha çok tüketilme oranı $\% 45,6$, kırmızı etin tüketilme oranı ise $\% 53,4$ olarak belirlenmiştir. Erkek bireylerin kadın bireylere nazaran daha çok tavuk eti tüketmeyi tercih ettikleri sonucu tespit edilmiştir. Kırmızı etin daha çok tüketilme oranı tüm yaş gruplarında \%64,1, tavuk etinin tüketilme oranı 
ise \%35,9 olarak tespit edilirken, 31-40 yaş grubunda yer alan bireylerin diğer yaş grubunda yer alan bireylere göre daha çok tavuk eti tükettiği, 61-70 yaş grubunda yer alan bireylerin ise hiç tavuk eti tüketmediği belirlenmiştir. Eğitim grupları itibariyle, tüketicilerin $\% 52$ 'sinin daha çok tavuk eti, $\% 48$ 'inin ise kırmızı et tükettiği saptanmıştır. En yüksek tavuk eti tercihinin okuryazar grupta olduğu (\%77.8) belirlenmiştir. Aylık gelir gruplarında, tavuk etinin daha çok tüketilme oranı \%42, kırmızı etin daha çok tüketilme oranı ise \%58 olarak bulunmuştur. Gelir gruplarına bakıldığında, en fazla tavuk eti tercihinin geliri en düşük olan (1500-2500 TL) grupta görüldüğü belirlenmiştir. Tüketicilerin gelir grupları itibariyle gelir düzeyinin artmasıyla, genel olarak tavuk eti tüketiminin azaldığı ve kırmızı et tüketiminin arttığı sonucu ortaya çıkmıştır. Bingöl'de yapılan olan bir çalışmada, gelir grupları itibarıyla tüketicilerin tavuk eti ve kırmızı et tüketim tercihleri arasındaki ilişki anlamlı bulunmuş $(P<0,05)$, düşük ve orta gelire sahip ailelerin daha çok tavuk eti tükettiği, yüksek gelire sahip ailelerin ise kırmızı et tükettiği saptanmıştır (Karakaya ve İnci 2014). İkikat Tümer ve ark., (2016) tarafından Kahramanmaraş kent merkezinde yapılan çalışmada, erkeklerin kadınlara göre daha fazla tavuk eti tükettiği belirlenmiştir. Aynı araştırma sonucuna göre, ailelerin gelirleri arttıkça tavuk eti tüketimlerini arttırdıkları ancak belirli bir gelirden sonra ise kırmızı eti tavuk etine ikame ettikleri sonucuna varılmıştır. Ayrıca, çalışmada en fazla tavuk eti tüketiminin 41 yaş ve üzeri olan bireylerde olduğu ve eğitim durumu arttıkça tavuk eti tüketim miktarlarında da artış gözlendiği belirlenmiştir. Dokuzlu ve ark., (2013) tarafından Türkiye genelinde yapılmış olan araştırmada da gelir grupları itibariyle tavuk eti tüketiminin arttığı, ancak en yüksek gelir grubunda yer alan bireylerin kırmızı eti tavuk etine ikame ettikleri sonucu tespit edilmiştir. Kırşehir ilinde Karadavut ve Taşkın (2014)'ın yapmış olduğu çalışmada, bayanların erkeklere göre daha fazla tavuk eti tüketme eğilimde oldukları, 50 ve üzeri yaş grubunda tavuk eti tüketilme oranının $\% 60$ olduğu ve eğitim seviyesine bağı olarak kanatlı eti tüketiminin de arttığı bildirilmiştir.

\section{Ticari Piliç Etleri ile Köy Tavuğu Etlerinin} Karşılaştırılması ile ilgili Tüketici Görüşleri

Etlik piliçlerin köy tavuklarına göre çok hızlı pişmesini tüketicilerin büyük bir kısmının
(\%74) normal bir durum olarak görmedikleri ve aynı sürede pişmesi gerektiği fikrinde oldukları tespit edilmiştir. Tüketicilerin \%16'sı köy tavuklarının geç pişmesinin normal olduğunu ve bunun tavuğun yaşından kaynaklandığını ifade etmişlerdir. Etlik piliçlerin etini lezzetli bulan tüketicilerin oranı \%14, az lezzetli bulanların oranı $\% 42$, lezzetsiz bulanların oranı $\% 28$ ve hiç beğenmeyenlerin oranı ise \%16 olarak bulunmuştur. Tüketicilerin \%90'ı köy tavuğunu etlik pilice göre daha lezzetli, \%94'ü ise daha sağlıklı bulduklarını ifade etmişlerdir. Karakaya ve İnci (2014)'ün yapmış olduğu araştırmada, anket yapılan tüketicilerin $\% 51^{\prime} i$ piyasadaki tavuk etini lezzetli bulurken, \%35'i çok lezzetli, $\% 12$ 'si az lezzetli ve \%2'si ise lezzetsiz bulduğunu belirtmişlerdir. Tüketicilerin büyük bir kısmının (\%83) tavuk eti tercihinin, makul bir fiyatla kolaylıkla temin edebildiği durumda köy tavuğundan yana olacağı görülmüştür.

\section{Etlik Piliçlerin Kesim İşlemi ile ilgili Tüketici Görüşleri}

Tüketicilerin \%73'ü tavukların makinayla kesildiğini, \%25'i tavukların nasıl kesildiğini bilmediğini, \%2'si ise tavukların kasap tarafından kesildiğini belirtmişlerdir. Tavukların kesim işleminin İslami kurallara göre yapılıp yapılmadığı konusunda tüketicilerin büyük bir kısmı (\%41) emin olmadığını, \%35'i tavukların İslami kurallara uygun olarak kesilmediğini, \%14'ü kesim işleminin işletmelere göre değiştiğini ve \%10'u ise İslami kurallara göre kesildiğini ifade etmişlerdir. Elde edilen anket sonuçları, piyasada satılan tavukların İslami kurallara uygun kesilmiş olması durumunda, tüketicilerin $\% 50$ 'sinin tavuk eti tüketimini etkileyeceği, \%30'unun bu durumdan etkilenmeyeceği, \%16'sının ise kısmen etkileneceğini göstermiştir. Koç (2010) tarafından Bitlis ili Adilcevaz ilçesi kentsel alanında tavuk tüketen hane halkının \%68.48'inin, kırsal alanda yaşayanların ise \%73.34'ünün satın aldıkları etin hijyenik ortamda kesildiği ve yetkililerce denetlendiği görüşünde olduğunu bildirmiştir. Bingöl'de yapılan diğer bir araştırmada ise, bireylerin tavuk eti tüketimini olumsuz yönde etkileyen faktörler arasında ilk sırayı \%78 oranla "İslami usule göre kesilip kesilmemesi" almıştır (Karakaya ve İnci 2014). Piliçlerin İslami kurallara göre kesilmesinin tavuk eti tüketimini olumlu yönde etkileyeceği sonucu, Karakaya ve İnci (2014)'nin bulguları ile benzerlik göstermiştir. 
Çizelge 13. Sosyo-demografik özellikler itibariyle tüketilen et türünün dağılımı.

\begin{tabular}{lcc}
\hline & \multicolumn{2}{c}{ Tüketilen et türü (\%) } \\
\cline { 2 - 3 } Özellikler & Tavuk eti & Kırmızı et \\
\hline Cinsiyet & & \\
Erkek & 47,6 & 52,4 \\
Kadın & 44,5 & 55,5 \\
Ortalama & 45,6 & 53,4 \\
\hline Yaş & & \\
\hline 21-30 & 47,2 & 52,8 \\
31-40 & 58,5 & 41,5 \\
$41-50$ & 36,7 & 63,3 \\
$51-60$ & 37,5 & 62,5 \\
$61-70$ & 0,0 & 100 \\
Ortalama & 35,9 & 64,1 \\
\hline Eğitim durumu & & \\
\hline Okuryazar & 77,8 & 22,2 \\
Ilkokul & 42,1 & 57,9 \\
Ortaokul & 41,9 & 58,1 \\
Lise & 55,2 & 44,8 \\
Üniversite & 43,2 & 56,8 \\
Ortalama & 52,0 & 48,0 \\
\hline Aylık gelir & & \\
\hline 1500-2500 & 56,0 & 56,7 \\
2501-3500 & 48,0 & 58,0 \\
3501-4500 & 46,7 & 53,3 \\
$4501-5500$ & 26,1 & \\
5501 ve üstü & 33,3 & \\
Ortalama & 42,0 & \\
\hline & & \\
\hline
\end{tabular}

\section{Sonuç ve Öneriler}

Bu çalışmada, tüketicilerin, genelde 21-30 yaş grubunda, üniversite mezunu, 1500-2500 TL aylık gelire sahip ve memur statüsünde olan erkek bireylerden oluştuğu belirlenmiştir. Tüketicilerin büyük bir kısmı, günümüzde tüketilen gıdaların kalite yönünden daha önceki yıllara göre daha iyi olduğunu düşünmektedir. Ancak, bazı yanlış ve sorumsuzca açıklamalar nedeniyle piyasada satılan piliç etlerinin sağlıksız olduğu kanısına sahip olduğu anlaşılmıştır. Tüketicilerin önemli bir bölümü, piyasadaki etlik piliçlerin genetik yapılarıyla oynandığından dolayı etlerinin doğal olmadığını, tv kanallarında tavuk eti konusunda yapılan olumsuz açıklamaların çoğuna katıldıklarını ve bu durumdan etkilenerek tavuk eti tüketimini azalttıklarını belirtmişlerdir.

Tüketicilerin yarısından fazlasının (\%55), sağlıklı beslenmek için tavuk etinin mutlaka tüketilmesi gerektiğine inandıkları belirlenirken, tüketicilerin yine yarıdan biraz fazlasının (\%53) protein ihtiyacı için tavuk eti yerine daha çok kırmızı eti tercih ettikleri saptanmıştır. Tüketicilerin, kırmızı eti daha çok, güvenli, sağlıklı, besin değeri yüksek ve lezzetli bulduğu için, tavuk etini ise genelde daha ucuz olduğu için tercih ettikleri tespit edilmiştir. Tüketicilerin, piyasada satılan tavuk etlerine yeterince güvenememeleri, organik piliç veya köy tavuğunu ise piyasada bulamamaları tavuk eti tüketimini azaltan faktörler arasında sayılabilir. Tüketicilerin önemli bir kısmının, köy tavuğunu yetiştirme şartları, sağlık ve lezzet açısından etlik piliçlere göre daha çok önde gördüğü ve tüketim noktasında bulabildiği takdirde tercihinin köy tavuğundan yana olacağı sonucu belirlenmiştir. Tüketicilerin sosyo-demografik özellikleri ile tavuk eti tüketimi arasında istatistiki olarak anlamlı ilişkiler belirlenmemiş, ancak, genelde tüketicilerin sadece yarıdan fazlasının sağlıklı beslenme açısından tavuk etinin tüketilmesi gerektiğine inanmış olması beklenmeyen bir sonuçtur. Tüketicilerin önemli bir kısmının, etlik piliç üretimi konusunda olumsuz algı oluşturmaya yönelik açıklamalardan (özellikle sağlık ve kesimle ilgili konularda) etkilenerek tavuk eti tüketimini azalttığı belirlenmiştir. Erkek bireylerin kadınlara göre, 40 yaşından küçük olan bireylerin ise 40 yaş 
ve üzerindeki bireylere göre daha çok tavuk eti tüketmek istedikleri saptanmıştır. Okuryazar grubunda olan bireylerin diğer eğitim grubundaki bireylere göre ve 1500-2500 TL aylık geliri olan bireylerin diğer gelir grubunda olan bireylere göre daha fazla tavuk eti tüketmek istediği belirlenmiştir. Tüketicilerde, yaş ve gelir düzeyi arttıkça tavuk eti yerine kırmızı et tüketiminde artış gözlenmiştir. Bu durum, ileri yaşlardaki tüketicilerin tavuk etinin sağlıklı olup olmaması konularındaki tartışmalardan daha çok etkilendiklerini göstermektedir. Anket yapılan tüketicilerin büyük bir kısmı, etlik piliç üretiminde, hormon, antibiyotik, GDO'lu yem hammaddeleri ve kanserojen nitelikte olabilecek bazı katkı maddelerinin kullanıldığını ve bu durumun sağıı açısından sakıncalı olduğunu belirtmişlerdir. Cinsiyet, yaş ve eğitim özellikleri itibariyle tüketicilerin genel olarak, etlik piliçlerin modern işletmelerde sağlıklı olarak üretildiklerine inanmadıkları saptanmıştır. Tüketiciler, tavukların kesimhanelerde İslami kurallara göre kesilip kesilmemesi durumundan genelde haberdar olmamakla birlikte, büyük bir kısmının tavukların işletmede makinayla kesildiğini düşündüğü ve tavukların İslami kurallara uygun kesilmesinden emin oldukları takdirde tüketicilerin yarısının olumlu etkileneceği ve tavuk tüketimini artırabileceği sonucuna ulaşılmıştır. Bu sonuçlara göre, tüketicilerin piyasadaki tavuk etleri hakkındaki olumsuz algılarını değiştirebilmek açısında şunlar önerilebilir;

- Etlik piliç üretiminde hormon, antibiyotik vb. sağııksız ve kanserojen nitelikteki katkıların kullanılmadığı tüketicilere en etkili araç ve yöntemlerle anlatılarak tüketicilerin bilinçlenmesi sağlanmalıdır.

- Tavuk eti ve ürünleri arz zincirinin daha şeffaf hale getirilmesi ve tüketicilerin yetiştirme, kesim ve dağıtım sürecinin nasıl işlediğini bilmesi durumunda tüketicilerin bu ürünlere olan güveni artacaktır.

- Özellikle, yabancı ülkelerde bile helal sertifikalı piliç eti üretimi yapılırken, Türkiye'de "İslami kesim" konusundaki tüketicilerin kafasındaki soru işaretleri ortadan kaldırılarak tartışma konusu olmaktan çıkarılmalıdır.

- Gıda güvenirliğini, kalitesini ve sağlıklı olduğunu garanti eden sertifikalar ve işaretlerin çeşitli iletişim kaynakları kullanılarak tüketiciye tanıtılması, inandırılması ve bu eğitimin sürdürülebilir olması yönünde strateji ve politikaların geliştirilmesi gereklidir.

- Etlik piliç endüstrisinde, pazarlama stratejileri belirlenirken, üretimin sadece teknolojik ve ekonomik boyutuna değil, sağlıklı ve güvenilir olması boyutuna da büyük önem verilmelidir.

- Tüketicilerin, artan refah düzeyi ile organik piliç eti için daha fazla para ödemeye hazır olmaları, üreticilerin organik tavuk eti üretimi konusunda teşvik edilmeleri ve desteklenmeleri gerektiği sonucunu ortaya koymuştur.

- Organik etlik piliç üretimi belirli bir düzeye ulaşıncaya kadar, en azından bir geçiş sistemi olarak serbest etlik piliç yetiştiriciliği teşvik edilmeli ve yaygınlaştırılmalıdır.

¥: Bu çalışma 2. Yazarın yüksek lisans tezinden türetilmiştir.

\section{Kaynaklar}

Açıkgöz, Z., Özkan, K., 1996. Yumurta tüketiminin beslenme ve sağlık üzerine etkisi. Hayvancılık' 96 Ulusal Kongresi.18-20 Eylül, s. 175-186, Bornova-İzmir, Türkiye.

Altan, Ö., Yalçın, S., Koçak, Ç., 1993. Toplumun değişik kesimlerinde yumurta tüketim alışkanlığı ve tüketimi etkileyen etmenler. Uluslararası Tavukçuluk Kongresi 93. s.178194. İstanbul, Türkiye.

Ayvazoğlu Demir, P.. Aydın, E., 2018. Hormon ve antibiyotik kullanımına ilişkin olumsuz haberlerin tüketicilerin tavuk eti tüketim alışkanlıklarına etkisi (Kars ili örneği). MAE Vet Fak Derg, 3 (1): 55-63.

Baş, T., 2008. Anket. Araştırma Yöntemleri Dizisi:2, Seçkin Yayıncılık, 5. Baskı, Ankara.

Bircan, H., Eleroğlu, H., Arslan, R., 2017. Sivas kent merkezinde tavukçuluk ürünlerinin tüketimi ve tüketime etki eden faktörler. Türk Tarım-Gıda Bilim ve Teknoloji Dergisi. (5):12, 1609-1614.

BESD-BiR, 2016. Beyaz Et Sanayicileri ve Damızlıkçıları Birliği Derneği, www. besdbir.org (Erişim tarihi: 08.07.2019).

Büyüknisan, O., 2008. Adana illi kentsel alanda tavuk eti tüketim yapısı. Çukurova Üniversitesi, Fen Bilimleri Enstitüsü, Tarım Ekonomisi Anabilim Dalı, Yüksek Lisans Tezi, Adana.

Cevger, Y., Aral, Y., Demir, P., Sarıözkan, S., 2008. Ankara Üniversitesi Veteriner Fakültesi intern öğrencilerinde hayvansal ürünlerin tüketim durumu ve tüketici tercihleri. Ankara Üniversitesi Veterinerlik Fakültesi Dergisi 55: 189-194.

Çelik, Y., Şengül, T., 2001. Şanlıurfa ili kentsel alanında tüketicilerin yumurta tüketim düzeyleri ve tüketim alışkanlıklarının 
belirlenmesi. Hayvansal Üretim 42(2): $53-$ 62.

Dokuzlu, S., Barış, O., Hecer, C., Güldaş, M., 2013. Türkiye'de tavuk eti tüketim alışkanlıkları ve marka tercihleri. Uludağ Üniversitesi Ziraat Fakültesi Dergisi 27(2): 83-92.

Dölekoğlu, Ö.C., Yurdakul, O., 2004. Adana ilinde hane halkının beslenme düzeyleri ve etkili faktörlerin Logit analizi ile belirlenmesi. Akdeniz Üniversitesi İktisadi İdari Bilimler Fakültesi Dergisi 8: 62-86.

Ertürk, Y.E., Karadaş, K., Şahin, K., 2014. Iğdır illinde tüketicilerin tavuk eti ve balık tercihlerini belirleyen faktörler. 11. Tarım Ekonomisi Kongresi, 3-5 Eylül 2014, s. 164174. Samsun, Türkiye.

FAO, 2016. Food and Agriculture Organization of the United Nations. Livestock.

Hasipek, S., Aktaş, N., 1997. Türkiye'deki tavuk ürünlerinin insan beslenmesindeki yeri ve önemi. Uluslararası Tavukçuluk Konferansı YUTAV 97. s.15-22. İstanbul, Türkiye.

Hekimoğlu, B., Altındeğer, M., 2009. Kanatlı hayvan eti sektör raporu, sorunları ve çözüm önerileri. Samsun Tarım il Müdürlüğü, Strateji Geliştirme Birimi, Samsun.

İkikat Tümer, E., Akbay, C., Koşum, A., Ünal, S.A., 2016. Kahramanmaraş ili kent merkezinde tavuk eti tüketim alışkanlıkları ve tüketimi etkileyen faktörler. KSÜ Doğa Bilimleri Dergisi 19(4): 433-437.

İnci, H., Karakaya, E., Şengül, T., Söğüt, B., 2014. Bingöl ilinde kanatlı eti tüketiminin yapısı. Türk Tarım ve Doğa Bilimleri Dergisi 1(1): 17- 24.

İskender, H., Kanbay, Y., Özçelik, E., 2015. Artvin Çoruh Üniversitesi öğrencilerinin tavuk eti tüketim tercihleri. Fırat University Veterinary Journal of Health Sciences. 29, (1): 09-13.

IYKA, 2011. TRC1 Bölgesi Hayvancılık Durum Raporu. İpek Yolu Kalkınma Ajansı, Gaziantep, s. 1-136.

Karadavut, U., Taşkın, A., 2014. Kırşehir ilinde kanatlı eti tüketimini etkileyen faktörlerin belirlenmesi. Tekirdağ Ziraat Fakültesi Dergisi. 11:(1), 37-43.

Karakaya, E., İnci, H., 2014. Bingöl ili merkez ilçesi hane halkının kanatlı eti tüketim tercihleri.
Uludağ Üniversitesi Ziraat Fakültesi Dergisi 28 (1), 53-64.

Keskin, B., Demirbaş, N., 2012. Türkiye'de kanatlı eti sektöründe ortaya çıkan gelişmeler sorunlar ve öneriler. U. Ü. Ziraat Fakültesi Dergisi 26(1): 117-130.

Kızıloğlu, R., Kızılaslan, H., Dölek, G., 2013. Ekolojik yumurta ile endüstriyel yumurta tüketim tercihlerinin belirlenmesi üzerine bir araştırma. Tokat il merkez örneği. Alınteri 24(B): 20-28.

Koç, S., 2010. Bitlis ili Adilcevaz ilçesinde kentsel ve kırsal alanda kırmızı et ve tavuk eti tüketim yapısı. Yüksek Lisans Tezi. T.C. Yüzüncü Yıl Üniversitesi Fen Bilimleri Enstitüsü Tarım Ekonomisi Anabilim Dalı. Van.

Sayılı, M., 2006. Kuş gribinin tüketicilerin tavuk eti tüketim alışkanlıklarına etkisi (Tokat ili örneği). Gaziosmanpaşa Üniversitesi Ziraat Fakültesi Dergisi 23(2): 25-31.

Şengül, T., Çelik, Y., Doğan, Z., 2002. Şanlıurfa ili kentsel alanda tüketicilerin tavuk eti tüketim düzeyleri ve tüketim alışkanlıklarının belirlenmesi. Gaziosmanpaşa Üniversitesi Ziraat Fakültesi Dergisi 19(1): 145-150.

Taşkın, A., 2003. Gaziantep ili Nizip İlçesinde tüketicilerin tavuk eti ve yumurta tüketim düzeyleri ile tüketim alışkanlıklarının incelenmesi üzerine bir araştırma. Harran Üniversitesi Fen Bilimleri Enstitüsü Zootekni ABD, Yüksek Lisans Tezi, s. 60.

Terin, M., Bilgiç, A., Güler, İ.O., Yavuz, F., 2014. Türkiye'de süt ürünleri tüketim harcamalarına etki eden faktörlerin analizi: Çoklu Heckman Örneklem Seçicilik Sistem Yaklaşımı. Tarım Bilimleri Dergisi 21: 500515.

Topuzoğlu, A., Hıdıroğlu, S., Ay, P., Önsüz, F., İkiısıı, H. (2007). Tüketicilerin gıda ürünleri ile ilgili bilgi düzeyleri ve sağlık risklerine karşı tutumları. TSK Koruyucu Hekimlik Bülteni, 6 (4): 253-258.

TÜiK, 2016. Kümes hayvancılığı üretimi istatistikleri. Türkiye İstatistik Kurumu.

Uluat, Ş., 2002. Van ili merkez ilçede hayvansal gıda tüketim yapısı. Yüksek lisans tezi. YYü Fen Bilimleri Enstitüsü, Van. 